\title{
Ekspresi IL - $1 \beta$ pada Proses Kesembuhan Fraktur Os Femur Tikus Putih (Rattus norvegicus) Ovariektomi yang Diterapi dengan Ekstrak Cikal Tulang (Cissus quadrangularis)
}

\section{IL - 1 \& Expression in Fracture Healing on Os Femur of ovariectomized Rats (Rattus norvegicus) With Therapy Of Cissus Quadrangularis Extract}

\author{
Ira Sari Yudaniayanti, Bambang Sektiari Lukiswanto, M. Zainal Arifin \\ Departemen Klinik Veteriner, Fakultas Kedokteran Hewan, Universitas Airlangga, \\ Kampus C UNAIR Mulyorejo Surabaya 60115 \\ Email : irasari.vet@gmail.com
}

\begin{abstract}
This study aims to determine the potential of the Cissus quadrangularis extract to decreased the expression of IL-1 $\beta$ so that it can to inhibit bone resorption and osteoporosis fracture healing is not delayed union. Forty rats adapted for 1 week, and then divided into four groups with 10 replications. P0 (sham-operated + Osteotomy + $\mathrm{CMC} \mathrm{Na}$ ); P1 (ovariectomy + Osteotomy + CMC Na); P2 (ovariectomy + Osteotomy + Raloxifene $5.4 \mathrm{mg} /$ $\mathrm{kg}$ ); P3 (ovariectomy + Osteotomy + CQ $750 \mathrm{mg} / \mathrm{kg}$ ). Osteoporosis induced is made by bilateral ovariectomy in rats, then to make sure that osteoporosis is already happened, 8 weeks post-ovariectomy performed radiology examinations on the femur, then the osteotomy action. IL1- $\beta$ expression observations performed in at the $2^{\text {nd }}$ week and $6^{\text {th }}$ week after osteotomy through the immunohistochemistry examination. The results of immunohistochemistry examination in the $2^{\text {nd }}$ week showed an increased expression of IL1- $\beta$ in all groups of rat that did ovariectomy (P1, P2 and P3) were significantly different $(\mathrm{p}<0.05)$ with a rat group that didn't ovariectomy, as well P2 dan P3 were significantly different with P1. The Results of immunohistochemistry examination in the $6^{\text {th }}$ week showed the same pattern with the 2 nd week and there is increased IL1- $\beta$ expression in all groups of rat compared with the results of the examination in the 2nd week. Based on these results it can be concluded that Cissus quadrangularis extract and Raloxifen can decreased the expression of IL-1 $\beta$, and the results that don't significantly different, so that these both materials can to inhibit bone resorption and osteoporosis fracture healing don't get delayed union.
\end{abstract}

Keywords: Cissus quadrangularis Extract, IL - $1 \beta$, osteoporosis, ovariectomy, healing fracture of femur

\begin{abstract}
Abstrak
Penelitian ini bertujuan untuk mengetahui potensi ekstrak Cissus quadrangularis (Cq) dalam menurunkan ekspresi IL-1 $\beta$ sehingga mampu menghambat resorpsi tulang dan kesembuhan fraktur osteoporosis tidak mengalami keterlambatan (delayed union). Empat puluh ekor tikus putih diadaptasikan selama 1 minggu, selanjutnya dibagi menjadi empat kelompok dengan 10 ulangan. P0 (Non ovariektomi + Osteotomi + CMC Na); P1 (Ovariektomi + Osteotomi + CMC Na); P2 (Ovariektomi + Osteotomi + Raloxifene 5,4 mg/kg BB); P3 (Ovariektomi + Osteotomi + Cq $750 \mathrm{mg} / \mathrm{kg} \mathrm{BB}$ ). Induksi osteoporosis dilakukan dengan cara ovariektomi pada tikus, selanjutnya untuk memastikan bahwa sudah terjadi osteoporosis, 8 minggu pasca ovariektomi dilakukan pemeriksaan radiologi pada tulang femur, kemudian dilakukan tindakan osteotomi. Pengamatan ekspresi IL1- $\beta$ dilakukan pada minggu ke-2 dan minggu ke-6 pasca osteotomi melalui pemeriksaan imunohistokimia. Hasil pemeriksaan imunohistokimia pada minggu ke-2 menunjukkan adanya peningkatan ekspresi IL1- $\beta$ pada semua kelompok tikus yang dilakukan ovariektomi ( $\mathrm{P} 1, \mathrm{P} 2$ dan $\mathrm{P} 3$ ) yang berbeda nyata $(\mathrm{p}<0,05)$ dengan kelompok tikus yang tidak di ovariektomi, demikian juga P2 dan P3 berbeda nyata dengan P1. Hasil pemeriksaan imunohistokimia pada minggu ke-6 menunjukkan pola yang sama dengan minggu ke-2 dan terdapat peningkatan ekspresi IL1- $\beta$ pada semua kelompok tikus dibandingkan dengan hasil pemeriksaan pada minggu ke-2. Berdasarkan hasil penelitian ini dapat disimpulkan bahwa ekstrak
\end{abstract}


Cissus quadrangularis dan Raloxifen mampu menurunkan ekspresi IL-1 $\beta$ dengan hasil yang tidak berbeda nyata, sehingga kedua bahan tersebut mampu menghambat resorpsi tulang dan kesembuhan fraktur osteoporosis tidak mengalami keterlambatan (delayed union)

Kata Kunci : Ekstrak Cissus quadrangularis, IL - $1 \beta$, osteoporosis, ovariektomi, kesembuhan fraktur femur.

\section{Pendahuluan}

Osteoporosis adalah penurunan massa tulang yang menyebabkan fraktur traumatik atau atraumatik. Pengobatan osteoporosis yang sudah lanjut dengan komplikasi fraktur merupakan hal yang sangat sulit, dan memerlukan waktu lama dan biaya yang cukup besar (Jones et al., 2002). Defisiensi estrogen adalah salah satu faktor penting penyebab terjadinya osteoporosis. Defisiensi estrogen ini biasanya sering dialami wanita menopause maupun hewan-hewan betina yang diovariektomi (Kalu, 1991; Zaid et al., 2012). Defisiensi estrogen akan menyebabkan peningkatan produksi dari IL-1, IL-6, dan TNF $\alpha$, yang akan meningkatkan terjadinya osteoklastogenesis dan berlanjut dengan kehilangan tulang (Nazrun et al., 2012; Malutan et al., 2014). Estrogen juga merangsang ekpresi dari osteoprotegerin (OPG) dan TGF- $\beta$ oleh osteoblas dan sel stroma, yang selanjutnya berfungsi menghambat resorpsi tulang dan mempercepat/merangsang apoptosis osteoklas (Bell, 2003).

Sitokin IL-1 $\alpha$ dan IL-1 $\beta$ mempunyai peran penting terhadap destruksi tulang dengan cara membentuk osteoklas dan meningkatkan aktivitas osteoklas. Peranan utama IL-1 $\beta$ pada metabolisme tulang adalah menstimulasi resorpsi tulang dan menghambat formasi tulang (Ardo \& Sunariani, 2005). Berkaitan dengan peranan tersebut, maka sitokin IL-1 $\alpha$ dan IL-1 $\beta$ sebenarnya juga diperlukan pada fase awal maupun akhir pada proses kesembuhan tulang, keduanya berperan dalam merekrut sel mesenchymal (MSC). Selanjutnya MSC dirangsang untuk berdiferensiasi menjadi kondrosit dan osteoblas (Dimitriou et al., 2005; Schmidt-Bleek et al., 2009). Sitokin inflamasi yang berlebihan pada fase awal proses kesembuhan fraktur akan memperpanjang fase inflamasi, sehingga mengganggu pembentukan kalus dan meningkatkan waktu penyembuhan (Claes et al., 2012). Pada fase akhir kesembuhan fraktur yaitu fase remodeling, sitokin IL-1 $\alpha$ dan IL-1 $\beta$ sebenarnya juga diperlukan untuk meningkatkan aktivitas osteoklas yang berperan mengganti woven bone yang terbentuk pada tahap awal pembentukan kalus menjadi tulang lamelar untuk mengembalikan dan meningkatkan kekuatan tulang (Gerstenfeld et al., 2007), namun bila jumlahnya berlebihan akan menyebabkan gangguan pematangan kalus yang berpengaruh terhadap kekuatan tulang (Ke-RongDai, 2005).

Proses kesembuhan fraktur pada penderita osteoporosis berbeda dengan fraktur pada tulang yang normal. Pada penderita osteoporosis terjadi peningkatan jumlah dan aktivitas osteoklas. $\mathrm{Xu}$ et al. (2003), menyatakan adanya peningkatan aktivitas osteoklas meresorpsi tulang yang melebihi aktivitas osteoblas dalam pembentukan tulang pada penderita osteoporosis ataupun pada individu yang dilakukan ovariektomi akan menyebabkan gangguan penyembuhan fraktur yang terjadi, khususnya pada fase awal tahap kesembuhan fraktur. Aktivitas osteoblas sangat diperlukan pada fase awal penyembuhan fraktur untuk membentuk 
matriks tulang dan meregenerasi defek tulang yang terjadi, oleh karena itu bila aktivitas osteoblas lebih lambat daripada aktivitas osteoklas maka tahap awal pembentukan kalus akan terhambat.

Berbagai jenis obat telah dikembangkan untuk terapi osteoporosis, kebanyakan obat-obat tersebut bekerja dengan cara menghambat resorpsi tulang. Kilic and Sagiroglu (2013), menyatakan bahwa sesungguhnya terapi yang efektif untuk osteoporosis tidak hanya mampu menghambat resorpsi tulang, namun juga mampu menstimulasi pembentukan tulang terutama pada penderita osteoporosis yang mengalami fraktur. Potu et al.(2009) menyatakan bahwa rata-rata proliferasi dan aktivitas biologi dari osteoblas mengontrol rata-rata pembentukan tulang, oleh karena itu percepatan pertumbuhan osteoblas merupakan faktor kunci yang menentukan efisiensi perbaikan kerusakan tulang.

Tanaman Cikal tulang (Cissus quadrangularis/ (CQ) merupakan salah satu tanaman tradisional yang cukup potensial, karena tanaman ini mengandung kalsium, fosfat, dan fitoestrogen (Sabri dkk., 2009). Penelitian ekstrak tanaman cikal tulang (Cissus quadrangularis/(CQ) telah banyak dilakukan. Hasil penelitian-penelitian tersebut membuktikan bahwa tanaman ini efektif memperbaiki kerusakan tulang baik dikarenakan osteoporosis maupun akibat fraktur dengan cara pembentukan tulang baru. Dilaporkan beberapa penelitian bahwa tanaman cikal tulang (Cissus quadrangularis/(CQ) mempunyai efek osteogenik yaitu mampu meningkatkan deferensiasi dan aktivitas osteoblas (Parisuthiman et al., 2009; Potu et al., 2009; Sabri dkk., 2009; Shirwaikar et al., 2003; Deka et al., 1994). Namun demikian mekanisme efek osteogenik dari tanaman cikal tulang (Cissus quadrangularis/(CQ) belum dapat diketahui secara jelas dan juga belum pernah diteliti potensi tanaman ini untuk memperbaiki kerusakan tulang akibat fraktur yang terjadi pada penderita osteoporosis.

Berdasarkan uraian tersebut diatas, maka perlu dilakukan penelitian lebih lanjut untuk untuk mengetahui efektifitas tanaman cikal tulang (Cissus quadrangularis/(CQ) sebagai osteogenic agents yang mampu memperbaiki kerusakan tulang khususnya pada kejadian fraktur pada penderita osteoporosis dengan melihat kemampuan tanaman ini dalam mengendalikan aktivitas osteoklas dalam meresorpsi tulang, sehingga proses kesembuhan fraktur pada tulang yang mengalami osteoprosis tidak terganggu.

Tujuan dari penelitian ini adalah untuk mengetahui potensi ekstrak CQ dalam menurunkan ekspresi IL-1 $\beta$ sehingga mampu menghambat resorpsi tulang dan kesembuhan fraktur osteoporosis tidak mengalami keterlambatan (delayed union)

Hipotesis penelitian ini adalah Ekstrak tanaman cikal tulang (Cissus quadrangularis/(CQ) mampu menurunkan ekspresi IL-1 $\beta$ sehingga mampu menghambat resorpsi tulang dengan meningkatkan apoptosis osteoklas.

\section{Materi dan Metode}

Unit eksperimen yang digunakan pada penelitian ini adalah 40 ekor tikus putih (Rattus norvegicus) betina strain Wistar, berumur 2,5 bulan dengan berat berkisar antara 150 - 200 gram dan dalam keadaan sehat, yang ditandai dengan bulu mengkilat, mata bersinar dan gerakan yang lincah. Setiap tikus diberi pakan standar sebanyak $+10 \%$ dari berat badan (BR 511 : mengandung protein $20 \%$, Abu 5,92\%, serat kasar 5,01\%, Ca 0,88\% dan P $0,61 \%$ ) dan air minum aquabidestilata secara $a d$ libitum. Tikus ditempatkan pada kandang plastik 
dengan ukuran $40 \mathrm{~cm} \mathrm{X} 30 \mathrm{~cm}$ yang berisi 3 ekor tikus perkandangnya. Penggunaan Hewan Model telah dimintakan sertifikat Laik Etik Penelitian dari Komisi Etik Penelitian Fakultas Kedokteran Hewan Universitas Airlangga.

Obat-obat yang digunakan pada penelitian ini adalah Ketamil (ketamine $\mathrm{HCl}$, Ilium), Xyla (xylazine, Holland), Atropine Sulfas (PT. Ethica), Interflox (enrofloxacin).

Bahan uji yang digunakan dalam penelitian ini adalah tanaman Cikal tulang (Cissus quadrangularis) yang diperoleh dari Kebun Raya Purwodadi, Pasuruan, serta Raloxifene produksi Elly Lily, USA.

Pembuatan Ekstrak Tanaman Cikal tulang (Cissus quadrangularis) dengan metode sebagai berikut ; daging batang dan daun Cikal tulang (Cissus quadrangularis) dicuci, dipotong kecil-kecil, dianginanginkan pada udara kering dan dihancurkan atau digiling hingga menjadi serbuk kering. Serbuk kering diekstraksi menggunakan metode maserasi yaitu bahan kering direndam dengan etanol 96\%, kemudian dilakukan sonifikasi selama 10 menit. Selanjutnya diamkan selama semalam,dan disaring dengan kertas saring. Sisa/ampas ditambah lagi dengan etanol 96\% diaduk kembali seperti semula, langsung disaring. Langkah tersebut diulang hingga dihasilkan larutan ke-tiga. Ketiga larutan dikumpulkan dan diuapkan menggunakan alat rotavapour sehingga didapatkan ekstrak kental. Ekstrak kemudian disimpan dalam lemari pendingin agar tidak mudah rusak.

Empat puluh ekor tikus putih diadaptasikan selama 1 minggu, selanjutnya dibagi menjadi empat kelompok yaitu P0 (NOV), P1 (OV), P2, dan P3 masing-masing dengan 10 ulangan. Tikus kelompok P0 (NOV) (Kontrol negatif) : hewan coba normal tanpa pemberian obat, dilakukan sham operated dan osteotomi pada diafisis tulang femur, tikus kelompok
P1 (OV) (Kontrol positif): dilakukan ovariektomi dan dilakukan osteotomi pada diafisis tulang femur. P2 : tikus dilakukan ovariektomi, osteotomi pada diafisis tulang femur dan diberi terapi Raloxifene $(5,4$ mg/kg BB) (Potu et al. , 2009). P3 : tikus dilakukan ovariektomi dan osteotomi pada diafisis tulang femur dan diberi terapi ekstrak Cissus quadrangularis $750 \mathrm{mg} / \mathrm{kg}$ BB. Dosis Raloxifen dan ekstrak Cissus quadrangularis yang digunakan dalam penelitian ini berdasarkan penelitian yang sebelumnya (Potu et al., 2009).

Pembuatan model tikus defisiensi estrogen pada kelompok P1, P2, dan P3 dilakukan dengan ovariektomi bilateral. Prosedur ovariektomi dilakukan sesuai dengan metode yang dilakukan oleh Kaveh et al (2010), sebagai berikut; dilakukan insisi pada garis tengah (linea mediana) yaitu tepat di belakang/posterior umbilicus ke arah caudal. Panjang irisan dibuat secukupnya kira-kira 2-3 cm. Lapisan yang terinsisi meliputi kulit kemudian subkutan dan fasia, selanjutnya daerah di bawah subkutan dipreparir hingga terlihat garis linea alba. Muskulus daerah linea alba dijepit dan angkat sedikit, kemudian dilakukan insisi dengan menggunakan scalpel, hingga ruang abdomen terlihat. Setelah dinding abdomen terbuka, organ reproduksi dicari menggunakan kait ovariohisterektomi (Spay hook) dengan mengidentifikasi corpus uteri yang terletak di bawah vesica urinaria bagian dorsal, ditelusuri ke arah cranial kornua kiri sampai ditemukan ovarium kiri. Ligamentum dan pembuluh darah dijepit dengan mengunakan arteri klem tepat di sebelah cranial ovarium, pasang satu arteri klem lagi bersebelahan dengan klem pertama. Selanjutnya dilakukan pengikatan (ligasi) pembuluh darah beserta pengantung ovarium pada bagian anterior (depan) dari arteri klem dengan menggunakan benang absorbable (cat gut chromic 3-0), kemudian potong 
menggunakan scalpel diantara dua arteri klem yang telah terpasang tersebut dan dipastikan tidak terjadi pendarahan serta semua jaringan ovarium terangkat. Selanjutnya pada bagian caudal ovarium di pasang arteri klem dan dilakukan pengikatan (ligasi) pembuluh darah uterina beserta penggantungnya persis pada bagian posterior (belakang) arteri klem yang telah terpasang tadi dengan menggunakan benang absorbable (cat gut chromic3-0), setelah itu dilakukan pemotongan menggunakan scalpel di antara ligasi dan klem caudal. Klem dilepas dan sisa potongan jaringan uterus dibiarkan masuk kembali ke rongga abdomen. Selanjutnya, ovarium kanan ditarik keluar dari insisi, kemudian dilakukan prosedur yang sama seperti prosedur mengangkat ovarium kiri.

Pasca pengangkatan ovarium, rongga abdomen diirigasi mengunakan antibiotik (ampicilin) untuk mencegah infeksi. Selanjutnya, dilakukan penjahitan untuk menutup luka insisi. Lapisan peritonium dijahitkan dengan jahitan terputus sederhana menggunakan cat gut sedangkan kulit dijahit dengan pola matras silang menggunakan benang silk 3-0.

Prosedur osteotomi dilakukan setelah dilakukan pemeriksaan radiologi untuk memastikan bahwa tulang femur pada tikus ovariektomi sudah mengalami osteoporosis. Berdasarkan hasil pemeriksaan radiologi menunjukkan bahwa pada kelompok tikus yang diovariektomi terlihat adanya penurunan radiopasitas terutama pada bagian metafisis femur yang berbeda nyata dengan kelompok tikus yang tidak diovariektomi (Gambar 1 ).

Setelah dipastikan sudah terjadi osteoporosis, selanjutnya semua tikus pada kelompok P0 (NOV), P1 (OV), P2, dan P3 dilakukan prosedur osteotomi pada daerah diafisis femur dengan pemasangan intramedulary pin dengan ukuran diameter $1 \mathrm{~mm}$. Pemilihan osteotomi pada daerah diafisis karena proses kesembuhan fraktur pada daerah tersebut cukup komplek baik secara selular maupun molekular dan berpotensi cukup besar untuk terjadinya delayed union dan non union terutama pada kasus osteoporosis (Nikolaou et al, 2009; Kyllönen et al, 2015).

Seluruh prosedur operasi baik pada ovariektomi maupun osteotomi dlakukan anestesi menggunakan kombinasi ketamine $(50 \mathrm{mg} / \mathrm{kg}$ bb) dan xylazine (10mg/kg bb) (Flecknell, 2009). Perawatan pasca operasi adalah perawatan luka operasi dengan memberikan salep antibiotik dan injeksi intramuskular enrofloxacin $10 \mathrm{mg} / \mathrm{Kg} \mathrm{BB}$ selama 2 hari untuk terapi profilaksis, agar tidak terlalu mengganggu hasil penelitian.

Dua hari setelah dilakukan osteotomi pada kelompok P2 mulai diberikan raloxifine 5,4 mg/kg BB, P3 diberikan ekstrak tanaman Cissus quadrangularis $750 \mathrm{mg} / \mathrm{kg} \mathrm{BB}$, sedang pada PO (NOV) dan P1 (OV) diberikan CMC Na peroral. Masing-masing perlakuan pada kelompok tersebut diberikan selama 2 minggu untuk kelompok pengamatan 2 minggu (fase reparatif) dan 6 minggu untuk kelompok pengamatan 6 minggu (fase remodeling).

Pengamatan ekspresi IL1- $\beta$ dilakukan pada minggu ke-2 dan minggu ke-6 pasca osteotomi melalui pemeriksaan imunohistokimia. Hal ini bertujuan untuk mengetahui ekspresi IL1- $\beta$ pada awal dan akhir proses kesembuhan fraktur juga mengetahui peranan IL1- $\beta$ dalam kesembuhan fraktur. Pengumpulan sampel dilakukan dengan cara mengambil masing-masing 5 ekor tikus pada semua kelompok perlakuan baik pada pengamatan minggu ke-2 maupun ke-6, untuk dilakukan euthanasi dan nekropsi, kemudian diambil bagian tulang femur yang di osteotomi setelah dibersihkan dari muskulus yang ada disekitarnya dan dibuat preparat imunohistokimia. 
Pemeriksaan ekspresi Il-1 $\beta$ dilakukan menggunakan pewarnaan imunohistokimia. Jumlah sel pengekspresi IL-1 $\beta$ adalah jumlah sel pada sayatan jaringan tulang femur yang memberikan reaksi positif terhadap mouse monoclonal antibody (mAb terhadap IL-1 $\beta$ ) dengan metode Imunohistokimia yang diamati 5 lapang pandang.

Data kuantitatif dari penelitian ini yaitu ekspresi IL-1 $\beta$, dianalisis menggunakan SPSS 20.0 for windows software (SPSS, Chicago, IL, USA). Perbedaan diantara kelompok perlakuan dievaluasi menggunakan ANOVA, dilanjutkan dengan Uji Least Square Differences (LSD) (Ghozali, 2006).

\section{Hasil dan Pembahasan}

Hasil pemeriksaan imunohistokimia dan penghitungan ekspresi IL1- $\beta$ dapat dilihat pada Tabel 1, serta Gambar 2 dan 3. Hasil pemeriksaan imunohistokimia pada minggu ke-2 menunjukkan ada peningkatan ekspresi IL1- $\beta$ pada kelompok P1, P2 dan P3 yang berbeda nyata $(p<0,05)$ dengan kelompok tikus tidak di ovariektomi (P0). Hal ini menunjukkan bahwa ovariektomi dapat menyebabkan peningkatan produksi dari IL-1, IL-
6, dan TNFa lebih lanjut. Kelompok tikus PO, yaitu tikus yang tidak diovariektomi menunjukkan ekspresi IL1- $\beta$ paling rendah, hal ini dikarenakan pada kelompok ini tidak terjadi defisiensi estrogen. Dalam keadaan normal estrogen dalam sirkulasi mencapai sel osteoblas, dan beraktivitas melalui reseptor yang terdapat di dalam sitosol sel tersebut, mengakibatkan menurunnya sekresi sitokin seperti: Interleukin-1 (IL-1), Interleukin-6(IL-6)dan Tumor NecrosisFactor-Alpha (TNF- $\alpha$ ), merupakan sitokin yang berfungsi dalam penyerapan tulang ( Waters et al, 1999).

Ekspresi IL-1 $\beta$ pada P2 dan P3 pada minggu ke-2 lebih rendah dibanding P1, meskipun masih tinggi dibanding $\mathrm{P} 0$, hal ini dikarenakan proses yang sama dengan P1 yaitu akibat ovariektomi, tetapi karena P2 dan P3 diberikan terapi yaitu pada P2 dengan Raloxifen dan P3 dengan Cissus quadrangularis sehingga peningkatan ekspresi IL$1 \beta$ tidak terlalu tinggi. Raloxifen dapat menekan ekspresi IL-1 $\beta$ dengan cara mengurangi aktivitas osteoklas, karena obat antiosteoporosis ini termasuk golongan antiresoptif dengan mekanisme kerjanya diduga melibatkan $\mathrm{TGF}_{3}$ yang dihasilkan oleh osteoblas dan osteoklas yang berfungsi menghambat

Tabel 1. Rata-rata dan Standar Deviasi Ekspresi IL1- $\beta$ pada Fraktur Femur Tikus Putih (Rattus norvegicus) pada masing-masing Kelompok Perlakuan

\begin{tabular}{clll}
\hline No. & Kelompok Perlakuan & IL1- $\beta($ Mg ke-2) & IL1- $\beta$ (Mg ke-6) \\
\hline 1. & P0 (NOV + Osteotomi + CMC Na) & $4,8 \pm 1,3^{\mathrm{a}}$ & $6,8 \pm 1,3^{\mathrm{a}}$ \\
2. & P1 (OV + Osteotomi + CMC Na) & $11 \pm 2,12^{\mathrm{b}}$ & $16,8 \pm 1,8^{\mathrm{d}}$ \\
3. & P2 (OV + Osteotomi + RLX) & $7 \pm 1,41^{\mathrm{c}}$ & $11 \pm 1,6^{\mathrm{b}}$ \\
4. & P3 (OV + Osteotomi + CQ $)$ & $8 \pm 1,41^{\mathrm{c}}$ & $12 \pm 1,41^{\mathrm{b}}$ \\
\hline
\end{tabular}

Keterangan: - Superskrip yang berbeda pada kolom yang sama menunjukan ada -perbedaan yang nyata $(\mathrm{P}<0,05)$ di antara perlakuan. - Superskrip yang berbeda pada baris yang sama menunjukan ada perbedaan yang nyata $(\mathrm{P}<0,05)$ di antara perlakuan. 
deferensiasi osteoklas. Aksi raloksifen diperantarai oleh ikatan raloksifen pada reseptor estrogen (Cao et al.,2002; Rosen, 2005; Kanakamani and Tandon, 2008). Cissus quadrangularis menekan ekspresi
IL-1 $\beta$ selain dengan cara meningkatkan aktivitas osteoblas, juga mempunyai efek antimikrobial sehingga dapat menekan tingkat inflamasi (Potu et al., 2009).

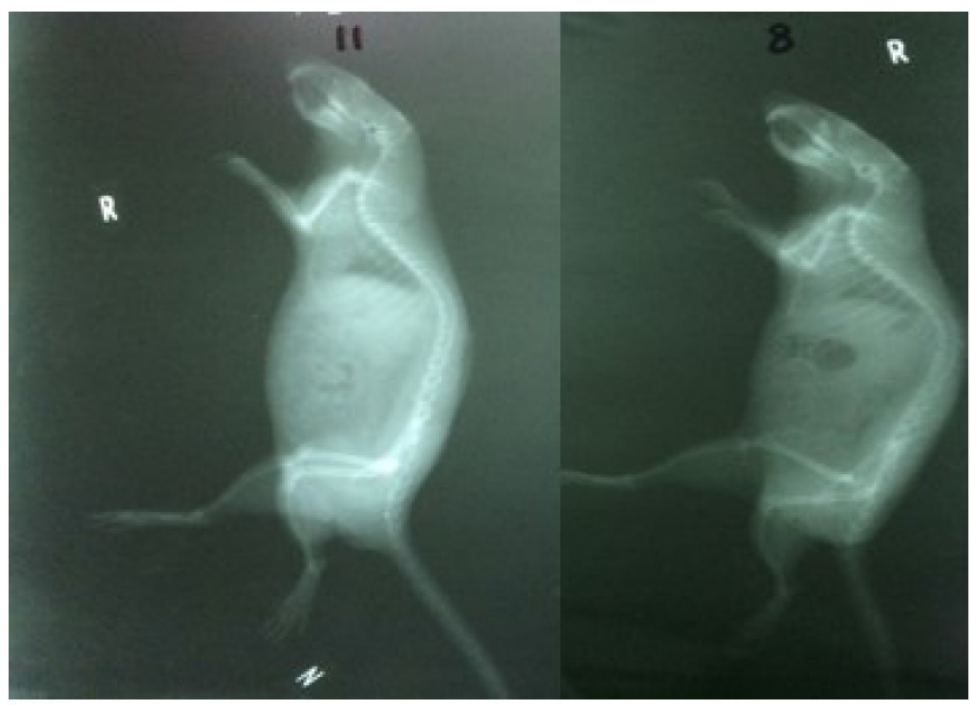

NOV

OV

Gambar 1. Gambaran Radiologi densitas tulang antara tikus yang tidak diovariektomi (NOV) dengan tikus yang diovariektomi (OV)

Ekspresi IL1- $\beta$ pada minggu ke-6, terjadi pola yang sama dengan minggu ke-2, yaitu ekspresi tertinggi terdapat pada kelompok P1 (OV), dan yang terendah pada kelompok P0(NOV) yang berbeda nyata $(\mathrm{p}<0,05) \quad$ dengan kelompok perlakuan yang lain.
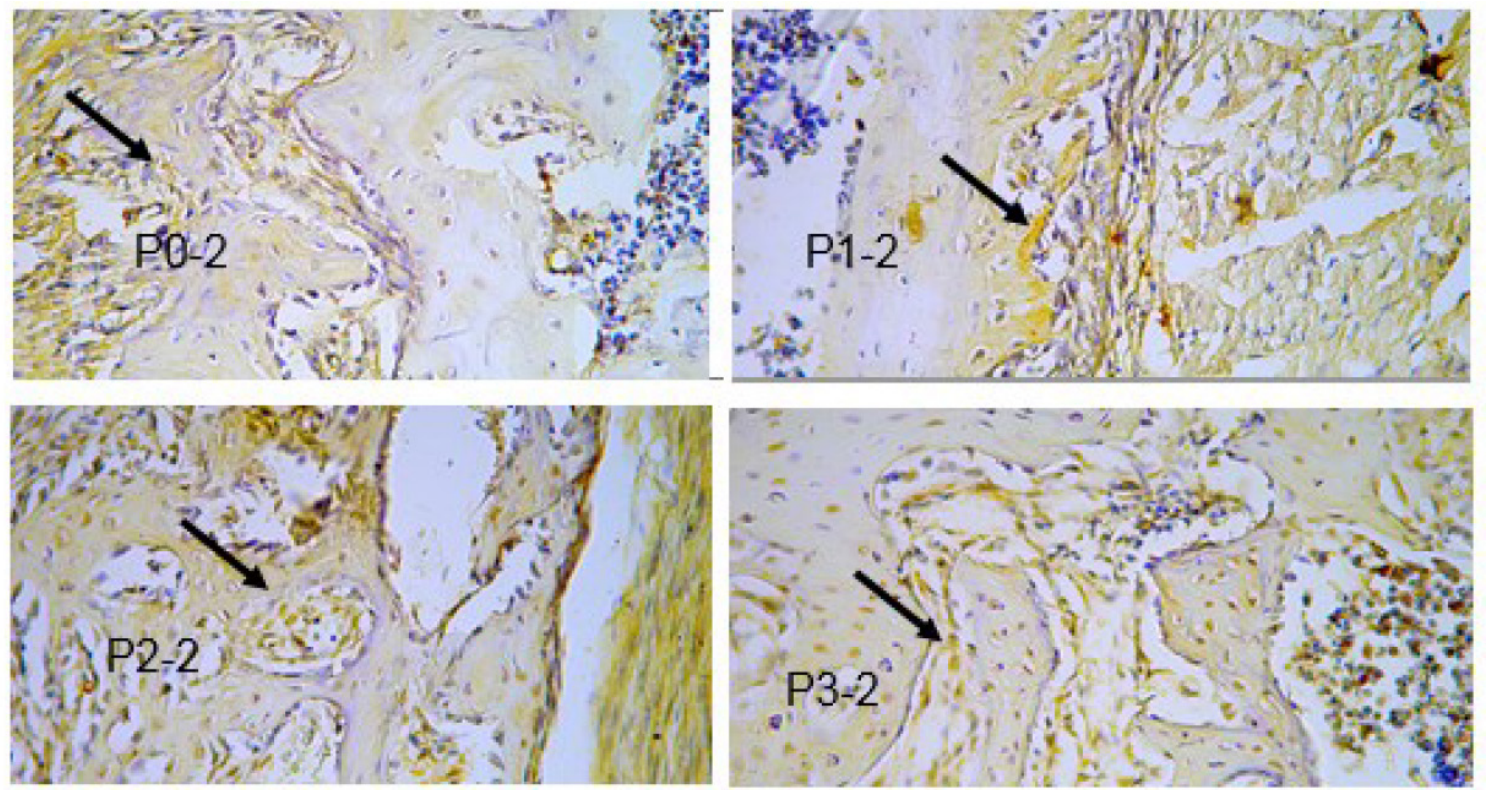

Gambar 2. Hasil pemeriksaan imunohistokimia ekspresi IL1- $\beta$ minggu ke-2 pada semua kelompok perlakuan tanda panah menunjukkan sel yang mengekpresikan IL1- $\beta$ (warna coklat) (pembesaran 400X) 

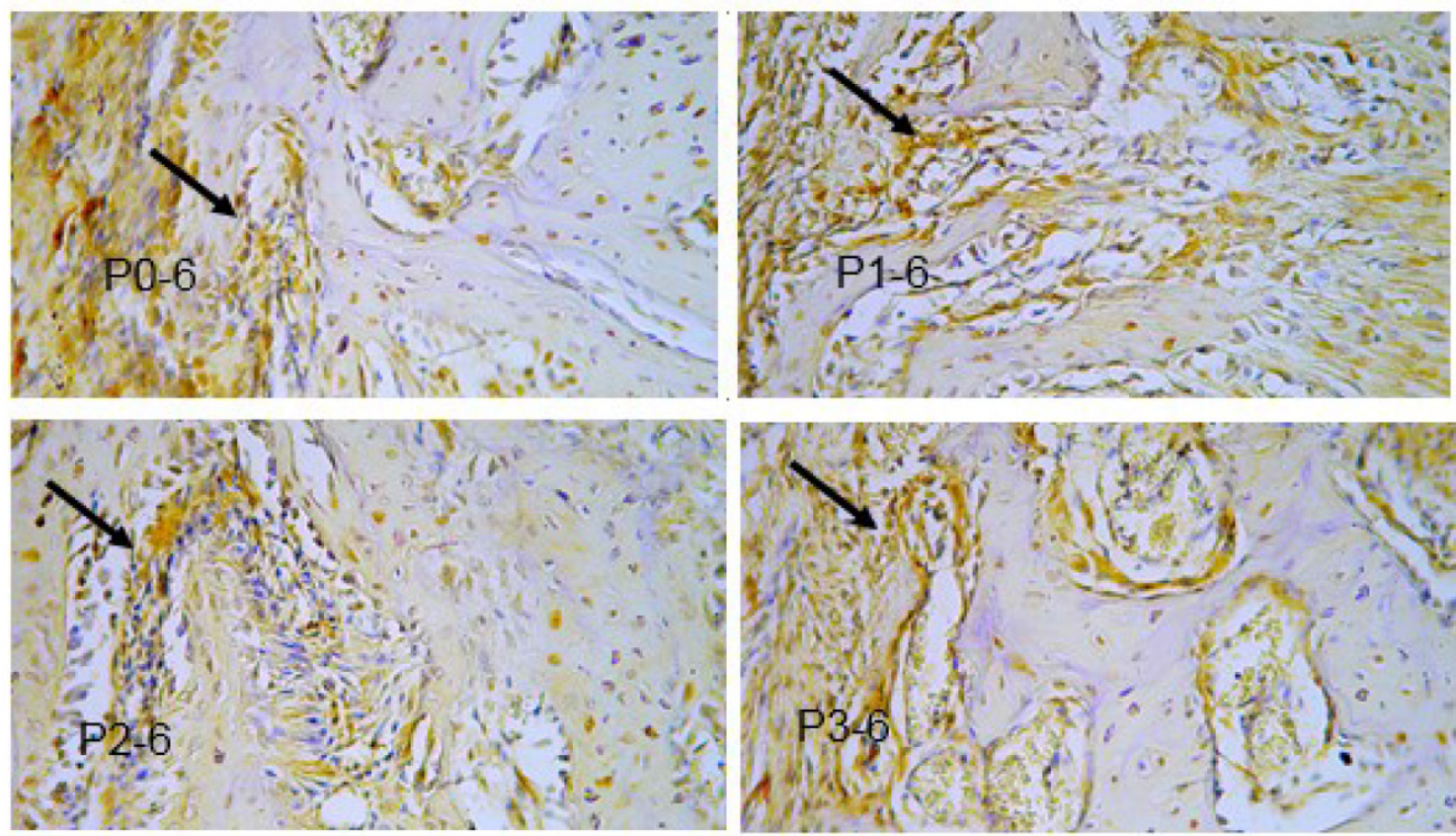

Gambar 2. Hasil pemeriksaan imunohistokimia ekspresi IL1- $\beta$ minggu ke-6 pada semua kelompok perlakuan tanda panah menunjukkan sel yang mengekpresikan IL1- $\beta$ (warna coklat) (pembesaran 400X)

Hasil pemeriksaan imunohistokimia pada minggu ke-6 menunjukkan peningkatan ekspresi IL1- $\beta$ pada semua kelompok tikus dibandingkan dengan hasil pemeriksaan pada minggu ke-2.(Gambar 4). Hal ini sesuai dengan pendapat Mountziaris and Mikos (2008), bahwa setelah fase proliferasi IL1- $\beta$ mengalami penurunan dan selanjutnya kadar IL1- $\beta$ akan meningkat lagi pada fase remodeling berkaitan dengan fungsi IL1- $\beta$ mendukung osteoklas dalam mengikis/merusak hard callus yang terbentuk dengan tujuan mengembalikan struktur asli dan kompetensi biomekanik tulang yang mengalami fraktur.

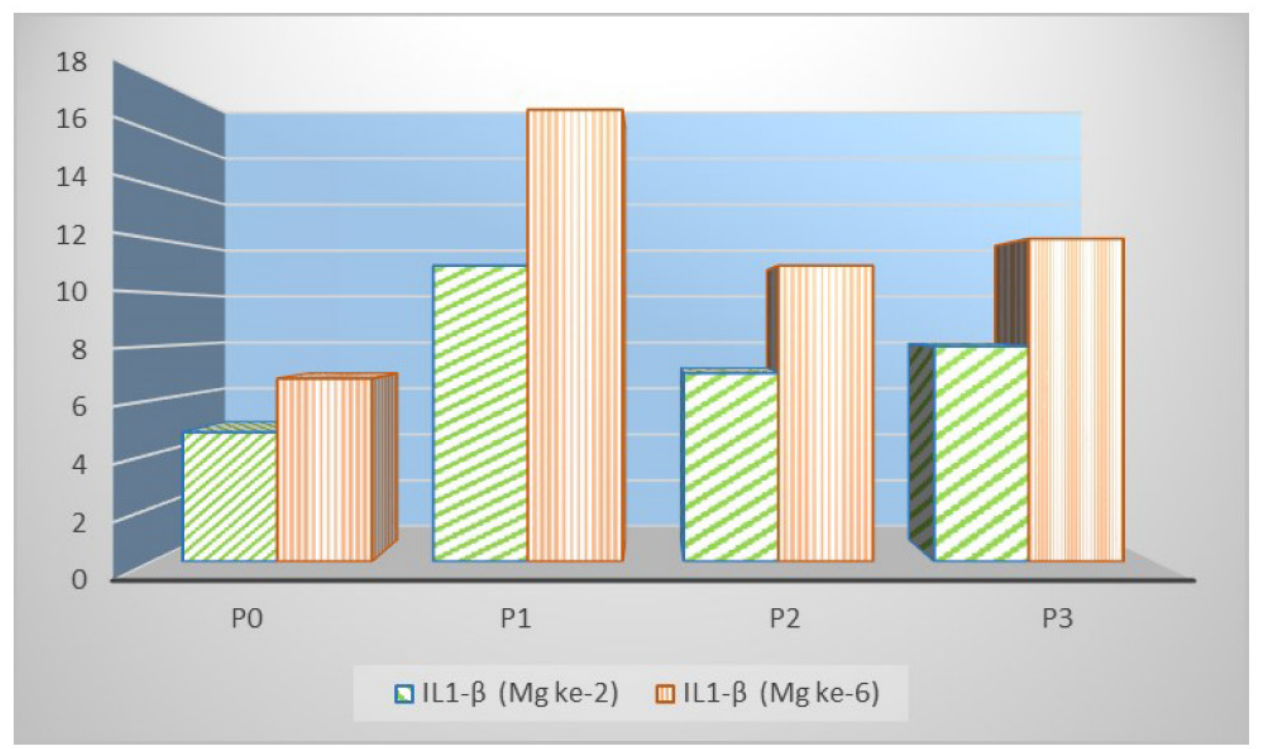

Gambar 4. Grafik Ekspresi IL1- $\beta$ pada minggu ke-2 dan ke-6 pada semua kelompok perlakuan 
Berdasarkan hasil penelitian ini, dapat membuktikan bahwa Cissus quadrangularis mampu menurunkan ekspresi IL1- $\beta$ pada tikus yang diovariektomi. Hal ini dibuktikan pada kelompok P2 dan P3, meskipun dalam kondisi defisiensi estrogen akibat ovariektomi, tetapi karena diterapi dengan raloxifen (P2) dan Cissus quadrangularis (P3), yang kedua bahan obat tersebut bekerja pada reseptor estrogen sehingga dapat membantu mengembalikan fungsi estrogen yang dalam keadaan normal bersirkulasi mencapai osteoblas, dan beraktivitas melalui reseptor yang terdapat di dalam sitosol sel tersebut, mengakibatkan menurunnya sekresi sitokin seperti:Interleukin-1 (IL-1), Interleukin-6 (IL-6) dan TumorNecrosis Factor-Alpha (TNF- $\alpha$ ), merupakan sitokin yang berfungsi dalam penyerapan tulang (Waters et al., 1999).

Yamaguchi (2002) menyatakan bahwa phytoestrogen yang terkandung dalam Cissus quadrangularis yaitu isoflavon, ligni, coumestan, triterpan, glikosida, dan asiklik yang mampu mengikat reseptor beta estrogen pada osteoblas dan bisa merangsang proliferasi osteoblast. Mekanisme molekuler yang menjelaskan potensi Cissus quadrangularis dalam meningkatkan osteogenesis masih harus dieksplorasi. Namun, beberapa bukti menunjukkan bahwa pensinyalan Wnt mungkin mempunyai pengaruh yang cukup berarti, karena jalur Wnt ini telah terbukti mempunyai peran penting dalam mengendalikan osteoblastogenesis dan pembentukan tulang (Potu et al, 2009).

Hasil yang sama juga ditunjukkan pada penelitian Muthusami et al (2011) yang menyatakan bahwa terapi ekstrak Cissus quadrangularis mampu menurunkan kadar IL1- $\beta$ pada media sell human osteoblast like SaOS-2, selanjutnya penurunan kadar
IL1- $\beta$ tersebut dapat memacu peningkatan protein IGFBP 3 yang berakibat penurunan proses degradasi protein yang menunjang proses kesembuhan tulang.

\section{Kesimpulan}

Berdasarkan hasil penelitian ini dapat disimpulkan bahwa ekstrak Cissus quadrangularis dan Raloxifen mampu menurunkan aktivitas osteoklas pada tulang osteoporosis yang ditandai dengan menurunnya ekspresi IL-1 $\beta$ dengan hasil yang tidak berbeda nyata, sehingga kedua bahan tersebut mampu menghambat resorpsi tulang dan kesembuhan fraktur osteoporosis tidak mengalami keterlambatan (delayed union).

\section{Ucapan Terima Kasih}

Terima kasih diucapkan kepada MenristekDikti yang telah mendanai penelitian ini melalui skim Program Penelitian Unggulan Perguruan Tinggi (PUPT), tahun anggaran 2015-2016

\section{Daftar Pustaka}

Ardo K, Sunariani J. 2003. The Role of Interleukin$1 \beta$, Interleukin-6, Tumour Necrosis Factor- $\alpha$ and Interferon $\gamma$ in Bone Remodelling Process during Orthodontic Treatment. University of Airlangga;316-20

Bell, NH. (2003). RANK ligand and the regulation of skletal remodeling. J Clin Invest; (111):1120-22.

Cao Y, Mori S, Mashiba T, Westmore MS, Ma L, Sato M. (2002). Raloxifene, estrogen, and alendronate affect the processes of fracture repair differently in ovariectomized rats. $J$ Bone Miner Res 2002;17-12:2237-46.

Claes, L., Recknagel, S., Ignatius, A. (2012). Fracture healing under healthy and inflammatory 
conditions. Nat Rev Rheumatol;8:133-43.

Deka, D.K., Lahon, L.C., Saikia, J., Mukit, A. (1994). Effect of Cissus quadrangularis in accelerating healing process of experimentally fractured radius - ulna of dog: A preliminary study. Ind J Pharmacol 26:44-8.

Dimitriou R, Tsiridis E, and Giannoudis P V. 2005. Current concepts of molecular aspects of bone healing, Injury (vol. 36), No. 12, pp. 1392-404. URL:http://www.ncbi.nlm.nih.gov/pubmed/ 16102764.

Flecknell, P. (2009). Laboratory Animal Anaesthesia. Academic Press is an imprint of Elsevier Edition 3rd.

Gerstenfeld LC, Edgar CM, Kakar S, et al, 2007. Osteogenic Growth Factors and Cytokines and Their Role in Bone Repair. In (Bronner F, FarachCarson MC, Mikos AG, eds). Engineering of Functional Skeletal Tissues. Springer-Verlag. London. 17-45.

Ghozali, I. (2006). Statitik Non-Parametrik Teori dan Aplikasinya dengan Program SPSS. Badan Penerbit Universitas Diponegoro. Semarang.

Jones, D.H., Kong, Y.Y., Penninger, J.M. (2002). Role of RANKL and RANK in bone loss and arthritis. Ann Rheum Dis;2:1132-9.

Kalu, D.N. (1991) The ovariectomized rat model of postmenopausal bone loss. Bone Miner.;15(3): 175-91.

Kanakamani, J., Tandon, N. (2008). Newer therapies in osteoporosis. Indian Journal of Rheumatology. Review Article.Vol.3, No 4; pp. 148-157

Kaveh, K., Ibrahim, R., Abu Bakar, M.Z., and Ibrahim, T.A. (2010). Osteoporosis Induction in Animal Model. Am. Jour. of Animal and Veterinary Sciences 5 (2): 139-145

Ke-Rong Dai and Yong-Qiang Hao. 2005. Quality of Healing Compared Between Osteoporotic Fracture and Normal Traumatic Fracture. Review. Department of Orthopaedics, Ninth People's Hospital, Shanghai Jiao Tong University, school of Medicine, 639 Zhizaoju Road, Shanghai, China
Killic, T.O. and Sagiroglu C. (2013). Anabolic Agents as New Treatment Strategy in Osteoporosis. Intech Open Science. hlm. 241-257.

Kyllönen, L., D’Este, M., Alini, M., Eglin, D. (2015). Local drug delivery for enhancing fracture healing in osteoporotic bone. Acta Biomaterialia $11412-434$

Malutan, A.M., Dan, M., Nicolae, C., Carmen, M. (2014). Proinflammatory and anti-inflammatory cytokine changes related to menopause. Prz Menopauzalny; 13(3): 162-168

Mountziaris, P.M, and Mikos, A.G. (2008). Modulation of the inflammatory response for enhanced bone tissue regeneration. Tissue Engineering Part B: Reviews; 14, 179-86

Muthusami, S., Ramachandran, I., Krishnamoorthy, S., Govindan, R., Narasimhan, S. (2011). Cissus quadrangularis augments IGF system components in human osteoblast like SaOS-2 cells. Growth Hormone \& IGF Research 21: 343-348

Nazrun, A.S., Norazlina, Norliza M., and Nirwana S.I. (2012). The Anti-Inflammatory Role of Vitamin E in Prevention of Osteoporosis. Advances in Pharmacological Sciences. Volume 2012,Article ID 142702, 7 pages

Nikolaou, V.S., Efstathopoulos, N., Kontakis, G., Kanakaris, N.K., Giannoudis, P.V. (2009). The influence of osteoporosis in femoral fracture healing time. Injury; $40: 663-8$.

Parisuthiman,D.,Singhatanadgit,W.,Dechatiwongse, T., Koontongkaew, S. (2009). Cissus quadrangularis extract enhances biomineralization through up-regulation of MAPK-dependent alkaline phosphatase activity in osteoblasts. In Vitro Cell. Dev.Biol.-Animal;45: 194-200.

Potu, B.K., Bhat, K.M.R, Rao, M.S., Nampurath, G.K., Chamallamudi, M.R., Nayak, S.R., Muttigi, M.S. (2009). Petroleum ether extract of cissus quadrangularis (linn.) enhances bone marrow mesenchymal stem cell proliferation and facilitates osteoblastogenesis. Clinics.;64(10):993-998.

Rosen dan Clifford.( 2005). Postmenopausal Osteoporosis. N Engl J. Med.;353: 595-603 
Sabri, M., Nurhidayat, Sigit, K., Priosoeryanto, B.P., Manalu, W. (2009). Analysis of phytochemical and mineral content of Sipatah-patah Plant (Cissus quandrangularis) from Aceh as osteoporosis premedication. J Rona Lingkungan 2: 109-117.

Schmidt-Bleek K, Schell H, Kolar P, Pfaff M, Perka C, Buttgereit F, Duda G and Lienau J. 2009. Cellular composition of the initial fracture hematoma compared to a muscle hematoma: A study in sheep, J Orthop Res (vol. 27), No. 9, pp. 1147-51. URL: http://www.ncbi.nlm.nih.gov/ entrez/query.fcgi?cmd=Retrieve $\& \mathrm{db}=$ PubMed \&dopt=Citation\&list_uids=19382195 Sfeir C, Ho L, Doll BA, et al (2005). Fracture Repair. In (Lieberman JR, Friedlander GE, eds). Bone Regeneration and Repair, Biology and Clinical Application Humana Press, Totowa. New Jersey. 21-44.

Shirwaikar, A., Khan, S., Malini, S. (2003). Antiosteoporotic effect of ethanol extract of Cissus quadrangularis Linn. on ovariectomized rat. J Ethnopharmacol 89: 245-250

Waters, K.M., Rickard, D.J., Gebhart, J.B. (1999). Potential roles of estrogen reseptor- $\alpha$ and $-\beta$ in the regulation of human oteoblast functions and gene expression. The menopause at the millenium. The Proceding of the 9th International Menopause Society World Congress on Menopause. October 17-21; Yokohama, Japan.

Xu, S.W., Yu, R., Zhao, G.F., Wang, J.W. (2003). Early period of fracture healing in ovariectomized rats. Chin J Traumatol. 6:160-6.

Yamaguchi, M. (2002). Isoflavone and bone metabolism: its cellular mechanism prevention role in bone loss. J. Health Sci. 48(3):209-220.

Zaid, S.S.M., Sulaiman, S.A., Othman, N.H., Soelaiman, I.-N., Shuid, A.N., Mohamad, N. and Muhamad, N. (2012). Protective Effects of Tualang Honey on Bone Structure in Experimental Postmenopausal Rats. J. Clinics, vol. 67 , no. 7 , pp. $779-784$. 